\title{
Honra, gênero e direito no Brasil republicano
}

\section{Keila Grinberg}

Sueann Caulfield. Em defesa da honra: moralidade, modernidade $e$ nação no Rio de Janeiro (19181940). Tradução de Elizabeth de Avelar Solano Martins. Campinas: Unicamp; Cecult, 2001. 393p.

Rio de Janeiro, setembro de 1920. A cidade preparava-se para a visita dos reis Alberto e Elizabeth da Bélgica. Os governos federal e municipal náo economizavam recursos para "tornar a cidade digna da visita do monarca”, reformando o porto, a avenida Rio Branco, trocando os tapetes do Congresso, limpando os monumentos públicos. A beleza exuberante, as avenidas oceânicas e as praças ajardinadas eram elementos fundamentais para abrilhantar a temporada do casal real no Brasil, mas não os mais importantes. Alguns dias antes de sua chegada, o prefeito Carlos Sampaio conclamou a população carioca de todas as classes para concentrar-se nos lugares por onde passariam o rei e a rainha, para dar-lhes as boas- vindas em nome da honrada família brasileira. Os reis da Bélgica representavam a honra, moralidade e a civilização moderna, valores com os quais as autoridades brasileiras pretendiam que as famílias brasileiras se identificassem. E o pedido foi obedecido: amplamente mobilizada, a populaçáo local correspondeu às expectativas, demonstrando aos convidados a hospitalidade e a simpatia pelas quais eram mundialmente conhecidos.

É possível que, naquela ocasião, estivessem misturados à multidão Manoel Joaquim de Souza e Maria Imaculada Pereira, protagonistas da cena seguinte, que também ocorreu no Rio de Janeiro, em 1923. No terceiro distrito policial, Maria Imaculada, menor de idade, acusou Manoel Joaquim de tê-la deílorado em troca de futuro casamento. A promessa, como depois foi descoberto, não passara de planejada enganação; conforme havia escrito a um amigo em Portugal, o autor da ofensa, apesar da desonra cometida, 
faria "sempre tudo para não casar", admitindo "casar só pela Polícia!". Pois três semanas depois, lá estavam Manoel Joaquim de Souza e Maria Imaculada Pereira casando-se na Polícia, restaurando a honra da família Pereira.

As duas cenas, aparentemente desconexas, retratam um tema comum: os sentidos atribuídos à categoria honra no Rio de Janeiro da primeira metade do século XX. No caso da visita do rei Alberto, tratava-se da honra nacional, expressa através dos ideais de modernidade, mas também da simpatia e hospitalidade dos cariocas; no caso de Manoel Joaquim e Maria Imaculada, tratava-se da honra sexual, maculada pelo defloramento. A uni-las, o papel conferido à preservação da família, tida então como base da nação brasileira. Situaçóes como esta, e principalmente a relação entre elas, são analisadas em profundidade por Sueann Caulfield em seu livro Em defesa da honra: moralidade, modernidade e nação no Rio de Janeiro (1918-1940), cuja excelente versão em português, publicada pelo Centro de Pesquisa em História Social da Cultura da Unicamp, acaba de chegar às estantes brasileiras.

Mais do que propriamente analisar estes casos, Caulfield con- fere historicidade à categoria de honra sexual, discutindo, ao longo do tempo, as relaçóes entre seus diversos significados para agentes sociais como juristas, oficiais da polícia, intelectuais, donas de casa, sedutores, namoradas, pais, filhos e mães solteiras, e sua função nos debates públicos sobre a modernização no Brasil. É assim que, a partir das mudanças nas relaçóes sociais e de gênero ocorridas desde o início do século, das quais a presença da mulher no mercado de trabalho é apenas a mais visível, a autora constrói uma narrativa efetivamente convincente acerca da centralidade da categoria de honra sexual para a compreensão do amplo processo de mudanças sociais, culturais e políticas que caracterizou a passagem da chamada Primeira República para a Era Vargas.

Para tanto, ela parte de quatrocentos e cinqüenta inquéritos e processos criminais ocorridos entre 1920 e 1940 - no total, foram cerca de dez mil queixas de defloramento, que estavam entre as mais freqüentes queixas criminais até a década de 1940, perdendo apenas para lesóes corporais e roubo, e lideravam de longe a lista de crimes sexuais até os idos de 1970 _ , para avaliar a forma pela qual 
juristas e juizes julgaram estes casos de conflitos sexuais privados. Exemplar, neste sentido, é o quinto capítulo, uma análise quantitativa e qualitativa da importância da cor no encaminhamento e na decisão dos processos originados por denúncias de crimes sexuais. Rejeitando a resposta fácil que explica todo comportamento de membros da elite jurídica a partir do racismo, ela transforma esta questão em debate complexo, mostrando que muitas variáveis — inclusive, evidentemente, açor - concorrem para a tomada de decisão a respeito de um processo. Mais do que avaliar o motivo que levava cada juiz ou jurista a tomar posição em determinado caso, a autora direciona sua análise para a própria forma pela qual eles tentavam estabelecer, através de debates e de formação de jurisprudência específica, uma definição clara do papel do Estado na defesa da honra das famílias.

$\mathrm{Na}$ primeira metade do século $\mathrm{XX}$, esta era tarefa das mais difíceis. Afinal, ao mesmo tempo que a legislação civil do novo regime considerava todos os cidadáos iguais perante a lei, as mulheres, segundo a legislação penal, ainda podiam ser classificadas como "honestas" ou "desonestas", “capazes” ou "incapazes", segundo o papel de cada uma dentro (ou fora) da família. No código penal de 1890 , as ofensas sexuais eram consideradas "crimes contra a segurança da honra e honestidade das famílias”, e cabia aos agentes da lei definir quais as mulheres cujas ofensas podiam ser consideradas, quais as situaçóes que mereciam atenção e, obviamente, quais os casos que ameaçavam a honra e a honestidade das famílias, sendo merecedores de punição. Em geral, as avaliaçóes de juristas e juizes dependiam de suas próprias concepçóes acerca da origem social e da cor das ofendidas e dos agressores, o que tornava ainda mais difícil a aplicação de uma lei única, fundada em princípios liberais e universais, a todas as situaçóes existentes, ainda que fosse este o objetivo de grande parte dos juristas republicanos. O que tornava estas definiçóes problemáticas era a existência simultânea de duas concepçóes divergentes de honra, presentes tanto na lei quanto na jurisprudência: a noção genericamente definida como patriarcal de honra, centrada na família, e a definição liberal de honra, tida como uma virtude individual. Embora todos os jurisias defendessem 
esta última, não deixavam de imbuí-la, em seus discursos e pareceres, de suas próprias concepçôes de moralidade e honestidade.

Afinal, os costumes da sociedade carioca mudavam muito mais rápido do que as caracterizaçóes que a seu respeito faziam os juristas: comportamentos que antes eram considerados escandalosos aos olhos da chamada boa sociedade, como a presença de mulheres desacompanhadas em bondes e trens ou a freqüência feminina a festas noturnas, agora faziam parte do cenário da cidade. Assim, ao mesmo tempo que a igualdade entre os cidadãos era considerada uma marca fundamental da modernidade que se pretendia alcançar, a defesa da honra sexual das mulheres (feita por homens) também o era. Só que estas funções eram incompatíveis: ou os cidadãos eram iguais perante a lei, e a honra feminina náo seria objeto de legislação específica, ou a honra sexual das mulheres era objeto desta legislação específica, e portanto de preocupação do poder público, e os cidadãos e cidadãs não seriam tratadas igualmente pela lei.

A partir da década de 1920 , esta última opção passou a ser cada vez mais questionada entre os membros da sociedade carioca. Contra ela, havia as feministas, que reivindicavam tratamento igualitário entre homens e mulheres na lei, como a supressão de atenuantes para crimes passionais baseados na defesa da honra, comumente utilizados por maridos e namorados enganados; havia as chamadas "mulheres modernas", não mais recolhidas em suas casas ou sob a guarda de seus maridos, que pautavam suas açóes de acordo com diversos critérios de moralidade, muito distintos daqueles cunhados pelo já antigo código penal de 1890; e, finalmente, havia a nova geração de juristas que, ao combater aquilo que consideravam ser as tradições retrógradas e perversas da definição de honra do código penal, acreditavam estar lutando contra os costumes patriarcais e autoritários que, apesar do regime republicano e do fim da escravidão, ainda imperavam na sociedade brasileira.

As atitudes destes atores eram importantes para a redefinição legal dos conceitos de honra e virgindade. É neste sentido que se pode entender, por exemplo, a campanha do Conselho Brasileiro de Higiene Sexual contra os crimes passionais. Para seus membros, a veneração à 
castidade feminina era a responsável pelo alto número de assassinatos relacionados com a honra sexual e pela enxurrada de queixas de defloramento que assolavam as delegacias de polícia. A exaltação da honra sexual já não era vista como uma marca da civilização, como o fora no início do século, mas sim como uma noção anacrônica que incentivava os exageros sexuais e exibia o atraso nacional. No fim da década de 1930, juristas identificados com esta tendência estavam elaborando o novo código penal, introduzindo mudanças que ficaram célebres no direito criminal brasileiro: a partir da legislação de 1940, a "emoção ou paixão" não excluía mais a responsabilidade penal (embora ainda fosse atenuante), o que permitia, pelo menos, alguma punição dos assassinos de esposas e os antigos "crimes contra a segurança da honra e honestidade das famílias" foram divididos em "crimes contra a família” - bigamia, abandono ou maus-tratos de crianças, adultério - e "crimes contra os costumes" - estupro, atentado ao pudor, sedução, corrupção de menores e rapto. Note-se, aí, que a palavra sedução substituiu o defloramento e, principalmente, que o conceito de honra da família foi suprimido do texto deste código. Assim, a nova lei dirigiu seu foco de preocupação para a proteção dos chamados menores, em vez de centrar-se na preocupação com a virtude feminina.

Embora estes juristas achassem que a produção de textos legais encontrava-se fora do domínio da política, Sueann Caulfield é bastante convincente em argumentar o contrário. Analisando o processo de reformulação da legislação sobre o assunto e a forma como as queixas de crimes sexuais eram recebidas e respondidas em meados da década de 1930, ela argumenta que a honra foi ponto central de debate entre os grupos que disputavam poder no início do governo Vargas e à época de estabelecimento do Estado Novo. Foi assim que a palavra tornou-se chave na retórica do novo regime, sendo usada para definir valores familiares, para simbolizar o espírito da chamada "raça brasileira", que seria beneficiada pela miscigenação, e para expressar o direito aos benefícios sociais então regulamentados pelo Estado, já que trabalhador honrado era aquele que tinha carteira de trabalho. Ao mesmo tempo, a forma como a família foi definida nas constituiçóes 
de 1934 e 1937 no código penal de 1940 demonstrou que, entre a concepção de família de feministas e juristas liberais e aquela defendida pela Igreja, esta levou a melhor: a família continuou sendo considerada "indissolúvel" — a discussão acerca da questão do divórcio foi sepultada por décadas - e estava "sob a proteção do Estado"; pouco tempo depois, apesar dos ganhos feministas do início dos anos 1930, como o próprio direito de voto, o acesso de mulheres trabalhadoras ao mercado de trabalho passou a ser mais restrito, com o argumento de que era dever do Estado proteger as mães de família, reforçando o trabalho no ambiente doméstico, para fortalecer os laços familiares. $\mathrm{O}$ mesmo valia para os crimes sexuais: se eles não eram mais considerados ofensas contra a honra da família, tampouco o eram contra os indivíduos; tanto a honestidade quanto a integridade sexual das mulheres eram definidos como bens sociais coletivos, cuja responsabilidade de defender cabia ao Estado. É assim que a autora conclui que o governo Vargas, em resposta às supostas "desorganizaçóes sociais" do regime anterior, reformula o conceito de honra não só como instrumento de legitimação da autoridade, mas também como elemento de organização social.

Esta última afirmação é particularmente importante para evidenciar um dos argumentos centrais da autora, mas também por explicitar o tipo de abordagem elaborada neste livro. Como a esta altura já se deve saber, a categoria honra não é, aqui, utilizada apenas para ajudar na compreensão das relaçóes entre os homens e mulheres que viveram no Rio de Janeiro nas décadas de 1920 e 1930; mais do que isso, ela aparece como central para o entendimento da própria retórica de poder construída pelo governo Vargas, e para a história do direito civil e penal da primeira metade do século XX. Neste sentido, é justamente no cruzamento entre estas duas perspectivas - as distintas circunstâncias sociais nas quais a honra sexual feminina estava em jogo e a tentativa, por parte de juizes e juristas, de produzir um consenso acerca da sua definição jurídica que está situada uma das principais contribuiçóes deste trabalho: a conjugação da análise das relaçóes de gênero com a discussão a respeito do processo de formulaçáo do direito. Sem a referência aos conflitos cotidianos vivenciados pela popu- 
lação, é impossível entender as hesitações, as diferentes interpretações e as dificuldades de aplicação das leis. $\mathrm{O}$ processo de construção do direito só é plenamente entendido a partir das situaçóes concretas que provocaram sua discussão. Ao mesmo tempo, o entendimento do comportamento destas pessoas, de suas estratégias e conflitos, só pode ser percebido através de sua relação com a lei, responsável por definir, legislar e punir os responsáveis por atos ilegais.

Ao optar por esta abordagem Sueann Caulfield escreveu, simultaneamente, história do direito e história do gênero de excelente qualidade. Seu livro é leitura obrigatória para os estudiosos de ambos os temas, principalmente, para aqueles incomodados com as rígidas - e geralmente superficiais - fronteiras entre os campos do saber. 